\title{
Industrial Mineral Aggregate Amendment Affects Physical and Chemical Properties of Pine Bark Substrates
}

\author{
James S. Owen, Jr., ${ }^{1,2}$ \\ North Willamette Research and Extension Center, Oregon State University, \\ 15210 NE Miley Road, Aurora, OR 97002
}

Stuart L. Warren and Ted E. Bilderback

Department of Horticultural Science, North Carolina State University, Box 7609, Raleigh, NC 27695

\author{
Joseph P. Albano \\ U.S. Horticulture Research Laboratory, U.S. Department of Agriculture, \\ Agricultural Research Service, 2001 S. Fork Road, Ft. Pierce, FL 34945
}

Additional index words. media, phosphorus, bentonite, palygorskite, water

\begin{abstract}
Nonpoint source effluent containing nitrate $\mathrm{N}\left(\mathrm{NO}_{3}-\mathrm{N}\right)$ and phosphorus (P) from containerized nursery production has garnered local, regional, and national concern. Industrial minerals have long been used as absorbents, agrochemical carriers, and barriers to retain heavy metals. Our objective was to determine the effects of a palygorskitebentonite industrial mineral aggregate on the physical and chemical properties of a soilless substrate and the resulting impact on water and nutrient efficiency. The mineral aggregate had two particle size ranges $(0.25$ to $0.85 \mathrm{~mm}$ or 0.85 to $4.75 \mathrm{~mm})$ in combination with two temperature pretreatments [low volatile material (LVM) or regular volatile material (RVM)]. A representative substrate (8 pine bark: 1 coarse sand) of the southeastern United States nursery industry was also included in the study as a control. Cotoneaster dammeri C.K. Schneid. 'Skogholm' was grown in all substrates on collection pads that allowed for the quantification of daily influent and effluent volumes to calculate cumulative $\mathrm{NO}_{3}-\mathrm{N}$, ammonium $\mathrm{N}\left(\mathrm{NH}_{4}-\mathrm{N}\right)$, and dissolved reactive phosphorus (DRP) loss for 112 days. There was a $13 \%$ to $15 \%$ decrease in daily water application volume with no effect on Skogholm cotoneaster growth, which equated into a savings of 22 to $26 \mathrm{~L}$ per 14-L container in mineral aggregate-amended substrates compared with a sand-amended substrate (control). Mineral aggregate-amended substrates decreased $\mathrm{NH}_{4}-\mathrm{N}$ and DRP effluent $39 \%$ and $34 \%$, respectively, compared with the control. In addition, LVM and particle size 0.25 to $0.85 \mathrm{~mm}$ reduced effluent DRP compared with the 0.85 to $4.75-\mathrm{mm}$ RVM aggregate. Plant dry weight was unaffected by any of the treatments. Substantial nutrient content reduction in effluent and reductions in water application were achieved with amending pine bark with 0.25 to $0.85 \mathrm{~mm} \mathrm{LVM}$ industrial mineral aggregate. A 0.25 to $0.85-\mathrm{mm} \mathrm{LVM}$ industrial mineral aggregate pine bark-amended substrate reduced effluent DRP and $\mathrm{NH}_{4}-\mathrm{N}$ greater than $40 \%$ and reduced water application $15 \%$ or $26 \mathrm{~L}$ when compared with the industry representative substrate.
\end{abstract}

Environmental issues are at the forefront of agricultural concerns throughout the United States and the world (Malakoff, 1998; Nosengo, 2003). Nitrate $\mathrm{N}\left(\mathrm{NO}_{3}-\mathrm{N}\right)$

\footnotetext{
Received for publication 19 Jan. 2007. Accepted for publication 29 Apr. 2007.

This research was funded in part by USDA-ARS Floriculture and Nursery Initiatives grants (SCA \#58-6618-2-2027), Horticultural Research Institute, North Carolina Association of Nurserymen, Virginia Nursery and Landscape Association, and Oil-Dri Corporation of America.

We gratefully acknowledge Mary Lorscheider, William Reece, and Brian Jackson for technical assistance and William H. Swallow and Sandy Donaghy for statistical assistance.

${ }^{1}$ Former graduate research assistant.

${ }^{2}$ To whom reprint requests should be addressed; e-mail jim.owen@oregonstate.edu
}

substrates as a result of their availability, favorable physical properties, and lack of detrimental chemical constituents (Handreck and Black, 2002). A saleable containerized crop can be produced quickly in bark substrates; however, water and nutrient uptake efficiencies may be $50 \%$ or less (Lea-Cox and Ristvey, 2003; Warren and Bilderback, 2005).

Best management practices (BMPs) for containerized plant production (Yeager et al., 1997) have been implemented widely in the United States. Increased production efficiency has been achieved by optimizing rates of fertilization using controlled-release fertilizers (CRFs), reducing water volume applied, and adjusting water application timing. However, current BMPs recommend CRFs be used to maintain substrate solution $\mathrm{NO}_{3}-\mathrm{N}$ and $\mathrm{P}$ at $15 \mathrm{mg} \cdot \mathrm{L}^{-1}$ and $5 \cdot \mathrm{mg} \mathrm{L}^{-1}$, respectively. Current U.S. Environmental Protection Agency (USEPA) regulations are $10 \mathrm{mg} \cdot \mathrm{L}^{-1} \mathrm{NO}_{3}-\mathrm{N}$ as maximum contamination level (MCL) for groundwater and a goal for total P MCL not to exceed $0.05 \mathrm{mg} \cdot \mathrm{L}^{-1}$ in streams that drain into lakes or reservoirs and $0.10 \mathrm{mg} \cdot \mathrm{L}^{-1}$ for streams that do not (USEPA, 1987). Thus, nutrient concentrations in water discharged from nurseries may exceed these regulated concentrations and goals using current BMPs without costly infrastructural changes to continuously contain, clean, and reapply effluent.

Currently, substrate modification to increase uptake efficiency is not a BMP. There has been little change in substrates since introduction of bark substrates as a result of cost, acceptance, and availability. Engineering a soilless substrate of softwood bark to retain inputs could increase water and nutrient uptake efficiencies. Industrial minerals such as clay are used as absorbents, agrochemical carriers, and barriers to retain heavy metals (Murray, 2000) and have been considered recently as an amendment for container substrates (Handreck and Black, 2002; Reed, 1996). Clay minerals can improve physical properties and increase $\mathrm{pH}$ buffering capacity in bark and peat-based substrates (Handreck and Black, 2002; Reed, 1996). Empirically, Warren and Bilderback (1992) compared rates $(0,27,54,67$, and $\left.81 \mathrm{~kg} \cdot \mathrm{m}^{-3}\right)$ of arcillite in a pine bark substrate and reported arcillite increased available water (AW) and decreased ammonium $\mathrm{N}$ $\left(\mathrm{NH}_{4}-\mathrm{N}\right)$ and $\mathrm{P}$ effluent concentration with increasing arcillite rate. Growth of Sunglow azalea (Rhododendron L. 'Sunglow') increased curvilinearly with arcillite rate with the calculated optimum rate being $57 \mathrm{~kg} \cdot \mathrm{m}^{-3}$. Williams and Nelson (2000) investigated using small or large particle sizes of palygorskite, arcillite, or brick chips as a precharged source of $\mathrm{P}$ and $\mathrm{K}$ in peat:perlitebased substrates at $10 \%, 20 \%$, and $30 \%$ (by vol.). Phosphorus discharged in the leachate was reduced by the precharged palygorskite (6\% of added $\mathrm{P}$ leached) as compared with arcillite (18\% P leached), brick chips (11\% P leached), or a peat:perlite substrate $(37 \% \mathrm{P}$ leached). 
Interstratified palygorskite-bentonite is a common industrial mineral mined from the Fuller's Earth District in southern Georgia and northern Florida. Before being used in industrial applications, the mineral is screened to an appropriate particle size range with the most popular size for the agriculture industry being 0.25 to $0.85 \mathrm{~mm}$ (Moll and Goss, 1997). Industrial clay minerals dried at $\approx 121{ }^{\circ} \mathrm{C}$ are described as regular volatile material (RVM), which remain soft and have $8 \%$ to $12 \%$ water by weight (Moll and Goss, 1997). The RVM product can be subjected to further heating $\left(\approx 800{ }^{\circ} \mathrm{C}\right)$ and is then classified as a low volatile material (LVM), which is calcined or fixed, containing $0 \%$ to $1 \%$ water by weight (Robert Goss, Oil-Dri R\&D, personal communication, 2002). Our objective was to determine the effects of a palygorskite-bentonite industrial mineral aggregate on the physical and chemical properties of a soilless substrate and the resulting impact on water and nutrient efficiency.

\section{Materials and Methods}

Experimental design. The experiment was a 2 (aggregate particle size) $\times 2$ (mineral temperature pretreatment) factorial in a randomized complete block design with three replications with 10 plants in each replication. The treatments were pine bark-amended with palygorksite-bentonite mineral aggregate from Ochlocknee, GA (Oil-Dri Corp. of America, Chicago) with one of either two particle sizes ( 0.85 to $4.75 \mathrm{~mm}$ or 0.25 to 0.85 $\mathrm{mm})$ that had been pretreated at one of two temperatures $\left(\mathrm{RVM}=121^{\circ} \mathrm{C}\right.$ or $\mathrm{LVM}=800^{\circ} \mathrm{C}$ or less). All clay was added as an $8 \%$ (by vol.) substrate amendment. An additional substrate was included in the experimental design to represent the industry standard (control), which contained $11 \%$ sand (by volume) ( 8 pine bark: 1 sand). All substrates were amended with $0.6 \mathrm{~kg} \cdot \mathrm{m}^{-3}$ ground dolomitic limestone $\left[\mathrm{CaMg}\left(\mathrm{CO}_{3}\right)_{2}\right]$. The 112-d experiment was conducted from 16 May 2002 to 5 Sept. 2002 at the Horticulture Field Laboratory (lat. $35^{\circ} 47^{\prime} 37^{\prime \prime} \mathrm{N}$; long. $78^{\circ} 41^{\prime} 59^{\prime \prime} \mathrm{W}$ ) located at North Carolina State University, Raleigh. Research plots received $41.2 \mathrm{~cm}$ of rain (average of $1.5 \mathrm{~cm}$ rainfall per event) for a total of $27 \mathrm{~d}$.

Water and nutrient management. One hundred fifty rooted stem cuttings of Skogholm cotoneaster (Cotoneaster dammeri C.K. Schneid. 'Skogholm') liners with a $212-\mathrm{cm}(5.4 \mathrm{~cm} \times 5.4 \mathrm{~cm} \times 7.3 \mathrm{~cm})$ root ball were potted into 14-L containers (C-2000; Nursery Supplies, Chambersburg, PA) and placed on 15 separate plots, 10 containers per plot, which were designed to enable collection of all leachate leaving each plot. Leachate was unable to be collected when rainfall exceeded $0.8 \mathrm{~cm}$. Plots were $8 \times 1 \mathrm{~m}$ with a $2 \%$ slope. Containers were top-dressed with $60 \mathrm{~g}$ of $17 \mathrm{~N}-2.2 \mathrm{P}-9.6 \mathrm{~K}$ fertilizer (5- to 6month $17 \mathrm{~N}-5 \mathrm{P}_{2} \mathrm{O}_{5}-12 \mathrm{~K}_{2} \mathrm{O}$ Fast Start CRF with micronutrients; Harrell's Fertilizer Co., Lakeland, FL) that was hand-incorporated into the top $2 \mathrm{~cm}$ of the substrate at the time of treatment initiation (day 0). Irrigation water was applied to each container through pressure-compensated spray stakes [AcuSpray Stick $\left(200 \mathrm{~mL} \cdot \mathrm{min}^{-1}\right)$; Wade Mfg. Co., Fresno, CA]. Irrigation was applied in a cyclic manner with the irrigation volume divided equally among three applications applied at 1100, 1400, and 1700 HR eastern standard time (EST). Irrigation volume to maintain a target leaching fraction (LF, Eq.[1]) of 0.2 was applied to each container based on effluent values monitored daily and influent volumes that were measured biweekly.

$$
\mathrm{LF}=\frac{\text { effluent }(\mathrm{mL})}{\text { influent }(\mathrm{mL})}
$$

These data were used to determine water volume applied, water volume retained, and water use as affected by each treatment.

Effluent and substrate handling. The amount of effluent from each plot was measured daily and an aliquot of the effluent was analyzed colorimetrically using a ultravioletvisible spectrophotometer (Spectronic 1001 Plus; Milton Roy Co., Rochester, NY) for $\mathrm{NH}_{4}-\mathrm{N}$ (Chaney and Marbach, 1962), $\mathrm{NO}_{3}-\mathrm{N}$ (Calado et al., 1975), and dissolved reactive P (DRP) (Murphy and Riley, 1962).

Because there are no standard methods for mineral nutrient extraction from organic substrates, two extractants were used: deionized water and $0.1 \mathrm{M} \mathrm{KCl}$. Substrate total N $\left(\mathrm{NH}_{4}-\mathrm{N}+\mathrm{NO}_{3}-\mathrm{N}\right)$ and DRP were extracted from the substrate using a 1 substrate: 1.5 extract $\left(115 \mathrm{~cm}^{3}\right.$ substrate: $175 \mathrm{~mL}$ extractant) (Sonneveld et al., 1974). The substrate dilution was shaken for $1 \mathrm{~h}$ and filtered through $0.43-\mu \mathrm{m}$ filter paper (Whatman No. 1; Whatman, Florham Park, NJ). An aliquot of the filtered solution was then analyzed colorimetrically for $\mathrm{NH}_{4}-\mathrm{N}, \mathrm{NO}_{3}-\mathrm{N}$, and DRP as described previously.

In addition, macro- and micronutrients, cation exchange capacity (CEC), and exchangeable acidity [Al (aluminum), H (hydrogen)] were determined for each substrate on a volume basis (Tucker, 1984) using crushed (mortared and pestled) substrate samples dried at $60{ }^{\circ} \mathrm{C}$. The North Carolina Department of Agriculture (NCDA), Agronomic Division, Raleigh, performed standard analytical methods using Mehlich III extractant (Mehlich, 1984a), photometric determination (Mehlich, 1984b), and Mehlich buffer method (Mehlich et al., 1976).

Ammonium- $\mathrm{N}, \mathrm{NO}_{3}-\mathrm{N}$, and DRP remaining in the fertilizer prills at the end of the study were measured as follows. Nutrients were extracted from the fertilizer prills by blending the prills in $200 \mathrm{~mL}$ deionized water. After blending, the liquid was transferred quantitatively to a $1-\mathrm{L}$ volumetric flask that was adjusted to volume before removing an aliquot of the extractant supernatant. Ammonium-N, $\mathrm{NO}_{3}-\mathrm{N}$, and DRP in fertilizer prill extracts were quantified using the spectrophotometer as described previously.

Crop response. At $112 \mathrm{~d}$ after treatment initiation (DAI), two containerized plants were randomly chosen per plot (total of six plants per treatment) and removed. Tops were severed at the substrate surface and roots were placed over a screen and washed with a highpressure water stream to remove substrate. Tops and roots were dried at $65^{\circ} \mathrm{C}$ for $5 \mathrm{~d}$ and weighed. Because of their size, tops were ground initially using a Model 4 bench, 1 HP Wiley Mill (Thomas Scientific, Swedesboro, $\mathrm{NJ}$ ) to pass a $6.0-\mathrm{mm}$ sieve. The material from the tops and roots was further ground separately through a Foss Tecator Cyclotec 1093 sample mill (Analytical Instruments, LLC, Golden Valley, MN) to pass a $0.5-\mathrm{mm}$ sieve. Roots and tops were analyzed for N, P, $\mathrm{K}, \mathrm{Ca}, \mathrm{Mg}, \mathrm{S}, \mathrm{Fe}, \mathrm{Mn}, \mathrm{B}$, and $\mathrm{Mo}$ by the Agronomic Division of the (NCDA).

A nutrient budget was developed for each treatment to quantify the fate of recovered nutrients (RN; Eq. [2] from the applied CRF: absorbed by plant, lost in leachate, remaining in substrate (Mehlich III extractable), or remaining in the fertilizer prill.

$$
\begin{aligned}
\mathrm{RN}(\mathrm{mg})= & \sum_{\text {nutrient }}(\text { plant }+ \text { effluent } \\
& + \text { substrate }+ \text { fertilizer prills })
\end{aligned}
$$

The nutrient budget was used to calculate nutrient uptake efficiency (NUE, Eq. [3]) of $\mathrm{N}$ and $\mathrm{P}$.

$$
\begin{aligned}
& \text { NUE }(\%)= \\
& {\left[\begin{array}{c}
\text { plant absorbed nutrient }(\mathrm{mg}) \\
\text { applied nutrient }(\mathrm{mg})-\text { nutrient } \\
\text { remaining in CRF prill }(\mathrm{mg})
\end{array}\right]}
\end{aligned}
$$

To determine if the clay treatments increased the water-buffering capacity of the substrate, irrigation of the remaining plants was discontinued at the end of the study. Leaf gas exchange was measured on one plant from each replication between 1030 to $1130 \mathrm{HR}$ EST and 1530 to $1630 \mathrm{HR}$ EST for $4 \mathrm{~d}$ with a portable IR gas exchange system (LI-COR 6200; LI-COR, Lincoln, NE). Data were recorded for $30 \mathrm{~s}$ on the terminal $5 \mathrm{~cm}$ of an intact stem with $\approx 5$ fully expanded leaves. Measurements were taken under natural light in which photosynthetic active radiation remained greater than $1896 \mu \mathrm{mol} \cdot \mathrm{m}^{-2} \cdot \mathrm{s}^{-1}$. Average $\mathrm{CO}_{2}$ concentration within the chamber was $325 \pm 4 \mathrm{sE} \mu \mathrm{mol} \cdot \mathrm{mol}^{-1}$ and relative humidity was maintained at $43 \% \pm 1 \mathrm{sE}$. $\mathrm{CO}_{2}$ exchange rate (CER) and $g_{\mathrm{S}}$ were calculated using the LI-COR 6200 programs. In addition, dry weight and irrigation data were used to calculate water use efficiency of productivity (WUE $E_{P}$, Eq. [4]).

$$
\begin{aligned}
& \text { WUEP }_{P}\left(\mathrm{~mL} \mathrm{~g}^{-1}\right)= \\
& \qquad\left(\begin{array}{l}
\text { total irrigation volume } \\
\text { retained in substrate }(\mathrm{mL}) \\
\text { total plant dry weight }(\mathrm{g})
\end{array}\right)
\end{aligned}
$$

Substrate physical properties. Ten cylindrical aluminum cores, five $347.5 \mathrm{~cm}^{3}$ and five $100 \mathrm{~cm}^{3}$, were placed in fallow 
containers of each substrate. These containers were placed adjacent to the plants in the research study and received equivalent irrigation and rainfall as the corresponding treatment. After 9 weeks, the $347.5-\mathrm{cm}^{3}$ cores were extracted and total porosity, container capacity (CC), AW, and air-filled porosity were determined using the NCSU Porometer as described by Fonteno and Bilderback (1993). Unavailable water, held in the substrate at $1.5 \mathrm{MPa}$ or greater, was determined with the $100-\mathrm{cm}^{3}$ cores through a procedure developed by Milks et al. (1989). Bulk density $\left(D_{b}\right)$ was determined using oven-dried $\left(110^{\circ} \mathrm{C}\right)$ substrate in $347.5-\mathrm{cm}^{3}$ cores. Particle size distribution of $\approx 500 \mathrm{~cm}^{3}$ oven-dried substrate $\left(110{ }^{\circ} \mathrm{C}\right)$ was determined gravimetrically using 6.30, 2.00, $0.71,0.50,0.25$, or $0.106-\mathrm{mm}$ soil sieves. Particles $0.106 \mathrm{~mm}$ or less were collected in a pan. Sieves and pan were shaken for $5 \mathrm{~min}$ with a RX-29/30 Ro-Tap test sieve shaker (278 oscillations $/ \mathrm{min}^{-1}, \quad 150 \mathrm{taps} / \mathrm{min}^{-1}$ ) (W.S. Tyler, Mentor, OH).

Data analysis. All data were subjected to analysis of variance procedures (SAS Institute, 2001) with $\alpha \leq 0.10$ to reduce the risk of a type II error (Marini, 1999). Treatment means were compared using orthogonal contrast statements. PROC REG and PROC NLIN were used to further investigate linear and nonlinear segmented trends associated with water and nutrient data. Join points for segmented lines denoted as $X_{n}$ were determined using PROC NLIN.

\section{Results and Discussion}

Substrate physical properties. $\mathrm{CC}$ and AW were unaffected by mineral aggregate amendments, whereas RVM increased air space 3\% (by vol.) compared with LVM (Table 1). However, CC and AW pooled over mineral aggregate amended substrates increased CC 5\% (by vol.) and AW 4\% (by vol.) compared with the control (sandamended substrate). This increase represents $\approx 500 \mathrm{~mL}$ of AW per container of aggregateamended substrate more than the control. Thus, mineral aggregate-amended substrates increased container water-holding capacity without decreasing air space. Increased CC and AW were likely a result of the properties of the mineral aggregate other than particle size, because there were no notable differences in particle size distribution among the sand-amended and mineral aggregateamended substrates (data not presented). Spomer (1998) hypothesized substrates containing expanded clay have intrapores containing water that is available to the plant, thus increasing water-buffering capacity or the capacity to hold more AW. The mineral used in this study, palygorskite, is a fibrous mineral with zeolitic pores that retain water. In addition, Spomer (1998) reported a substrate amended with clay had increased air space and tortuosity, possibly resulting in greater water retention in the container system. Riviere et al. (1990) also reported a 4\% and $42 \%$ increase in total porosity and easily available water (available at 10 to $50 \mathrm{~cm}$ suction), respectively, when the clay rate increased in a brown peat-based substrate from $15 \%$ to $20 \%$ (by volume). Warren and

Bilderback (1992) found amending pine bark with arcillite $\left(0,27,54,67\right.$, or $\left.81 \mathrm{~kg} \cdot \mathrm{m}^{-3}\right)$ changed pore size distribution, which increased AW curvilinearly and decreased

Table 1. Physical properties of substrates amended (by volume) with $11 \%$ sand (control) or $8 \%$ Georgiana bentonite-palygorksite clay mineral aggregate with two particle sizes and two temperature pretreatments. ${ }^{\mathrm{z}}$

\begin{tabular}{|c|c|c|c|}
\hline \multirow[b]{2}{*}{ Treatment } & Container $^{y}$ capacity & Air $^{x}$ space & $\overline{\text { Available }^{\mathrm{w}} \text { water }}$ \\
\hline & \multicolumn{3}{|c|}{ 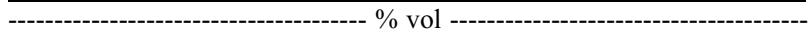 } \\
\hline Controlv $^{v}$ & $45^{* \mathrm{u}}$ & 38 & $15^{*}$ \\
\hline \multicolumn{4}{|c|}{ Temp. pretreatment ${ }^{t}$} \\
\hline LVM & $51^{\mathrm{s}}$ & 33 & 19 \\
\hline RVM & 50 & 36 & 19 \\
\hline \multicolumn{4}{|c|}{ Particle size (mm) } \\
\hline 0.25 to 0.85 & $50^{\mathrm{r}}$ & 35 & 19 \\
\hline 0.85 to 4.75 & 50 & 34 & 18 \\
\hline Temp (T) & $0.53^{\mathrm{q}}$ & 0.04 & 0.92 \\
\hline Size $(\mathrm{S})$ & 0.99 & 0.44 & 0.35 \\
\hline $\mathrm{T} \times \mathrm{S}$ & 0.45 & 0.84 & 0.31 \\
\hline
\end{tabular}

${ }^{\mathrm{z}}$ All substrates lay fallow under experimental field conditions for $60 \mathrm{~d}$ before analysis.

yPredicted as percent volume at drainage.

${ }^{x}$ Percent air space $=$ total porosity - container capacity.

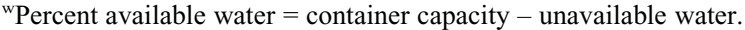

'Industry representative substrate $(\mathrm{n}=3) ; 8$ pinebark: 1 sand.

uAsterisks denote significant difference from the mean value of the pooled mineral aggregates determined by orthogonal contrast statements $(P \leq 0.05)$.

${ }^{\mathrm{t}}$ Mineral aggregate temperature pretreatment $(\mathrm{n}=3)$ : low volatile material $(\mathrm{LVM})=$ calcined, regular volatile material $($ RVM) $=$ pasteurized.

sPooled over mineral aggregate particle size $(n=6)$.

${ }^{r}$ Pooled over mineral aggregate temperature pretreatment $(n=6)$.

${ }^{\mathrm{q}} P$ values.

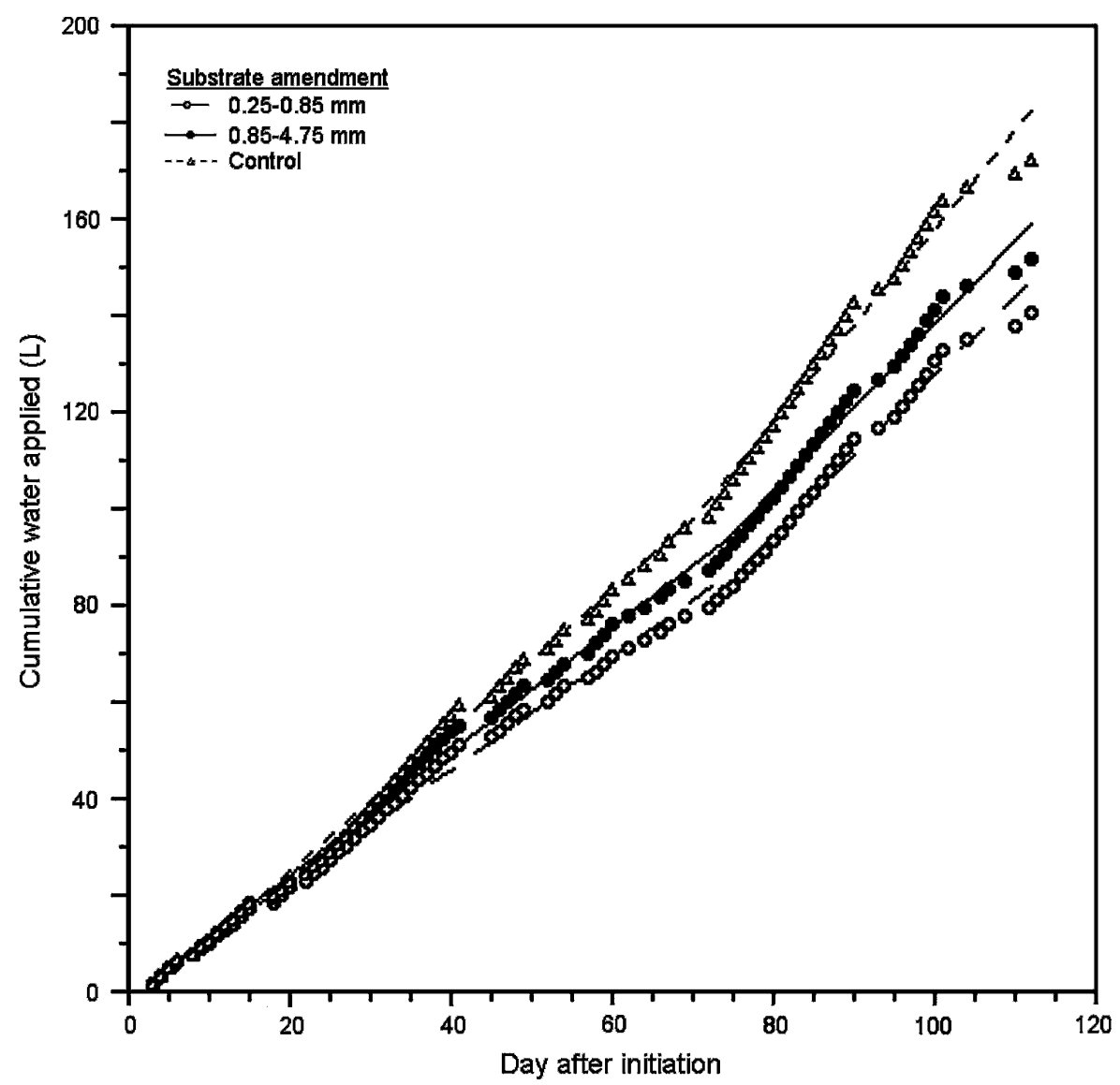

Fig. 1. Cumulative irrigation water applied to Skogholm cotoneaster grown $112 \mathrm{~d}$ in pine bark substrates amended (by volume) with $11 \%$ sand (control) or $8 \%$ Georgiana bentonite-palygorksite clay mineral aggregate with two particle sizes. Segmented linear models were calculated for 0.25 to $0.85 \mathrm{~mm}$ : if $\mathrm{x} \leq$ 74 , then $\mathrm{y}=-0.5+1.2 \mathrm{x}, R^{2}=0.99 ;$ if $\mathrm{x} \geq 74$, then $\mathrm{y}=-37.7+1.7 \mathrm{x}, R^{2}=0.98 ; 0.85$ to $4.75 \mathrm{~mm}$ : if $\mathrm{x} \leq$ 74 , then $\mathrm{y}=-1.3+1.3 \mathrm{x}, R^{2}=0.99$; if $\mathrm{x} \geq 74$, then $\mathrm{y}=-35.1+1.7 \mathrm{x}, R^{2}=0.98$; control: if $\mathrm{x} \leq 69$, then $\mathrm{y}=-4.3+1.5 \mathrm{x}, R^{2}=0.98$; if $\mathrm{x} \geq 69$, then $\mathrm{y}=-41.3+2.0 \mathrm{x}, R^{2}=0.98$. 
air space linearly but had no affect on total porosity.

$\mathrm{D}_{\mathrm{b}}$ (mean $\left.=0.21 \mathrm{~g} \mathrm{~cm}^{-3} \pm 0.001 \mathrm{sE}\right)$ was unaffected by mineral aggregate treatments, but $D_{b}$ pooled over industrial aggregates was less than the control (mean $=0.30 \mathrm{~g} \mathrm{~cm}^{-3} \pm$ $0.001 \mathrm{SE})$ (data not presented). Total porosity (mean $=84 \% \pm 0 \mathrm{SE})$ and unavailable water (mean $=32 \% \pm 0 \mathrm{SE}$ ) were also unaffected by any of the mineral aggregate treatments nor were they significantly different from the control (data not presented).

Substrate water-buffering capacity. LF was not different between treatments with an average of $0.22 \pm 0.006 \mathrm{SE}$ for the entire study (data not presented). However, the sand-amended substrate required $1.5 \mathrm{~L} \cdot \mathrm{d}^{-1}$ from 0 to 69 DAI to maintain a targeted LF of 0.2 , whereas substrates amended with either aggregate particle size range required an average of $1.25 \mathrm{~L} \cdot \mathrm{d}^{-1}$ between 0 and 74 DAI (Fig. 1). From 69 to 112 DAI, irrigation volume required to maintain a LF of 0.2 increased $33 \%$ to $2.0 \mathrm{~L} \cdot \mathrm{d}^{-1}\left(5.6 \mathrm{~mL} \cdot \mathrm{min}^{-1}\right)$ for the control reflecting the increase in plant size resulting from crop establishment and growth. From 74 to 112 DAI, irrigation volume for substrates amended with either aggregate particle size range increased to 1.7 $\mathrm{L} \cdot \mathrm{d}^{-1}$. This is a $13 \%$ to $15 \%$ decrease in daily water application volume. Mineral aggregate substrates, regardless of particle size, required 22 to $26 \mathrm{~L}$ less water per container over $112 \mathrm{~d}$ compared with the sand-amended substrate to produce equivalent Skogholm cotoneaster growth.

Chemical buffering capacity. Mineral aggregate amended substrates decreased $\mathrm{NH}_{4}-\mathrm{N}$ and DRP effluent load an average of $39 \%$ and $34 \%$, respectively, compared with the control (Figs. 2 and 3). Verhagen (personal communication, RHP Foundation, 2001) found the addition of a calcined clay component into peat-based substrates decreased water extractable $\mathrm{P} \approx 400 \%$ and increased $\mathrm{NH}_{4}$ retention $200 \%$ to $300 \%$.

Across all treatments, $80 \%$ to $90 \%$ of total $\mathrm{NH}_{4}-\mathrm{N}$ captured in the effluent over $112 \mathrm{~d}$ was lost in the first $7 \mathrm{~d}$ (Fig. 2). This most likely was a result of the water-soluble $\mathrm{N}$ (Fast Start) associated with this specific CRF. From 1 to 7 DAI, the sand-amended substrate lost $18.5 \mathrm{mg} \cdot \mathrm{d}^{-1} \mathrm{NH}_{4}-\mathrm{N}$, whereas the LVM and RVM aggregate-amended substrates lost 9.9 and $10.3 \mathrm{mg} \cdot \mathrm{d}^{-1} \mathrm{NH}_{4}-\mathrm{N}$, respectively. At $8 \mathrm{DAI}$, the rate of $\mathrm{NH}_{4}-\mathrm{N}$ loss decreased across all treatments. The rate of $\mathrm{NH}_{4}-\mathrm{N}$ from substrates amended with LVM aggregates decreased $97 \%$ to 0.28 $\mathrm{mg} \cdot \mathrm{d}^{-1}$, whereas the rate from the sandamended substrate decreased $94 \%$ to 0.57 $\mathrm{mg} \cdot \mathrm{d}^{-1} \mathrm{NH}_{4}-\mathrm{N}$. At 33, 37, and 39 DAI for the sand, RVM, and LVM aggregate-amended substrates, respectively, $\mathrm{NH}_{4}-\mathrm{N}$ loss from the container was negligible, a trend that continued for the rest of the 112-d study (Fig. 2). This was probably because of rapid oxidation of $\mathrm{NH}_{4}$ to $\mathrm{NO}_{3}$, root uptake, or leaching. Foster et al. (1983) reported $\mathrm{NH}_{4}$ $\mathrm{N}$ sorption to pine bark required $20 \mathrm{~d}$ to stabilize and equilibrate; however, our data

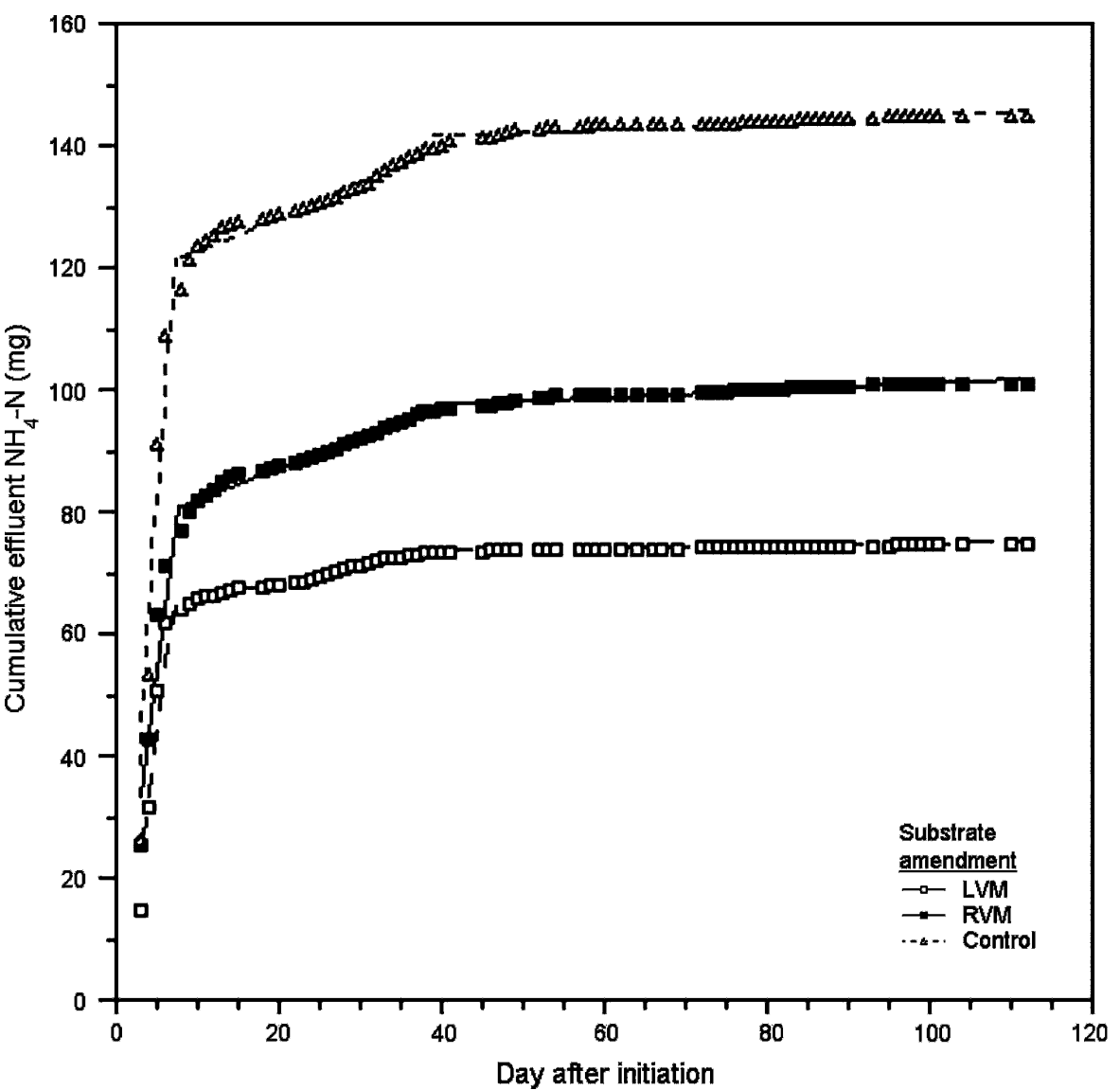

Fig. 2. Cumulative effluent ammonium for Skogholm cotoneaster grown $112 \mathrm{~d}$ in pine bark substrates amended (by volume) with $11 \%$ sand (control) or $8 \%$ Georgiana bentonite-palygorksite clay mineral aggregate with two particle sizes and two temperature pretreatments (LVM or RVM). Each container had $5.1 \mathrm{~g}$ of $\mathrm{NH}_{4}-\mathrm{N}$ surface incorporated at the initiation of the experiment. Segmented linear plateau models were calculated for each treatment: LVM: if $\mathrm{x} \leq 7$, then $\mathrm{y}=-7.3+9.9 \mathrm{x}, R^{2}=0.84$; if $7 \leq \mathrm{x} \leq$ 33 , then $\mathrm{y}=62.7+0.28 \mathrm{x}, R^{2}=0.97$; if $\mathrm{x} \geq 33$, then $\mathrm{y}=72.4+0.02 \mathrm{x}, R^{2}=0.80$; RVM: if $\mathrm{x} \leq 7$, then $\mathrm{y}=$ $2.4+10.3 \mathrm{x}, R^{2}=0.86$; if $7 \leq \mathrm{x} \leq 37$, then $\mathrm{y}=76.7+0.52 \mathrm{x}, R^{2}=0.95$; if $\mathrm{x} \geq 37$, then $\mathrm{y}=94.9+0.06 \mathrm{x}$; $R^{2}=0.92$; control: if $\mathrm{x} \leq 7$, then $\mathrm{y}=-16.8+18.5 \mathrm{x}, R^{2}=0.86$; if $7 \leq \mathrm{x} \leq 39$, then $\mathrm{y}=117.2+0.57 \mathrm{x}, R^{2}=$ 0.94 ; if $\mathrm{x} \geq 39$, then $\mathrm{y}=139.4+0.06 \mathrm{x}, R^{2}=0.82$. $\mathrm{LVM}=$ low volatile material; $\mathrm{RVM}=$ regular volatile material.

may simply be a result of the time for optimal edaphic conditions (i.e., $\mathrm{pH}$, water content, and temperature) to arise in the substrate to sustain Nitrosomonas sp., the nitrifying bacteria. Establishment of microbes to maximize nitrification occurs usually within 21 to $35 \mathrm{~d}$ after potting plants into a pine bark substrate (Niemiera and Wright, 1986).

Aggregate temperature pretreatment and particle size reduced effluent DRP content compared with the control (Fig. 3). There was no significant effect of interaction of temperature pretreatment and particle size. LVM and particle size 0.25 to $0.85 \mathrm{~mm}$ further reduced effluent DRP compared with the RVM aggregate and particle size of 0.85 to $4.75 \mathrm{~mm}$. Dissolved reactive $\mathrm{P}$ was lost linearly at a rate of $0.50 \mathrm{mg} \cdot \mathrm{d}^{-1}$ from 0 to 43 DAI for substrates amended with LVM aggregate, whereas substrates amended with RVM aggregate lost $0.71 \mathrm{mg} \cdot \mathrm{d}^{-1}$ from 0 to 46 DAI. The rate of DRP lost decreased at 43 or 46 DAI for substrates amended with LVM $\left(0.15 \mathrm{mg} \cdot \mathrm{d}^{-1}\right)$ or $\mathrm{RVM}\left(0.26 \mathrm{mg} \cdot \mathrm{d}^{-1}\right)$ resulting in $35 \%(17 \mathrm{mg})$ less DRP lost to leaching from 0 to $46 \mathrm{DAI}$ for substrates amended with LVM.

From 0 to 44 DAI, the rate of DRP loss decreased $29 \%$ when substrates were amended with 0.25 to $0.85 \mathrm{~mm}\left(0.52 \mathrm{mg} \cdot \mathrm{d}^{-1}\right)$ compared with substrates amended with 0.85 to $4.75 \mathrm{~mm}\left(0.7 \mathrm{mg} \cdot \mathrm{d}^{-1}\right)$ aggregates. After 45 DAI, the rate of effluent DRP decreased to $0.17 \mathrm{mg} \cdot \mathrm{d}^{-1}$ or $0.24 \mathrm{mg} \cdot \mathrm{d}^{-1}$ for 0.25 to 0.85 $\mathrm{mm}$ and 0.85 to $4.75 \mathrm{~mm}$ aggregate-amended substrates, respectively. This resulted in a $22 \%(10 \mathrm{mg})$ decrease in cumulative effluent DRP in pine bark substrates amended with aggregates of 0.25 to $0.85 \mathrm{~mm}$ compared with 0.85 to $4.75 \mathrm{~mm}$ from 45 to $112 \mathrm{DAI}$.

From 0 to 49 DAI, the control substrate lost $0.91 \mathrm{mg} \cdot \mathrm{d}^{-1} \mathrm{DRP}$, which was $29 \%$ to $79 \%$ greater than DRP loss from the mineral aggregate-amended substrates. This reflects a lower capacity of the industry substrate (pine bark: sand) to retain the oxyanion. After 49 DAI, the sand-amended substrate rate of DRP loss $\left(0.21 \mathrm{mg} \cdot \mathrm{d}^{-1}\right)$ was less than substrates amended with 0.85 to $4.75 \mathrm{~mm}$ $\left(0.24 \mathrm{mg} \cdot \mathrm{d}^{-1}\right)$ or RVM $\left(0.26 \mathrm{mg} \cdot \mathrm{d}^{-1}\right)$ aggregates (Fig. 3). The aggregates in these substrates 


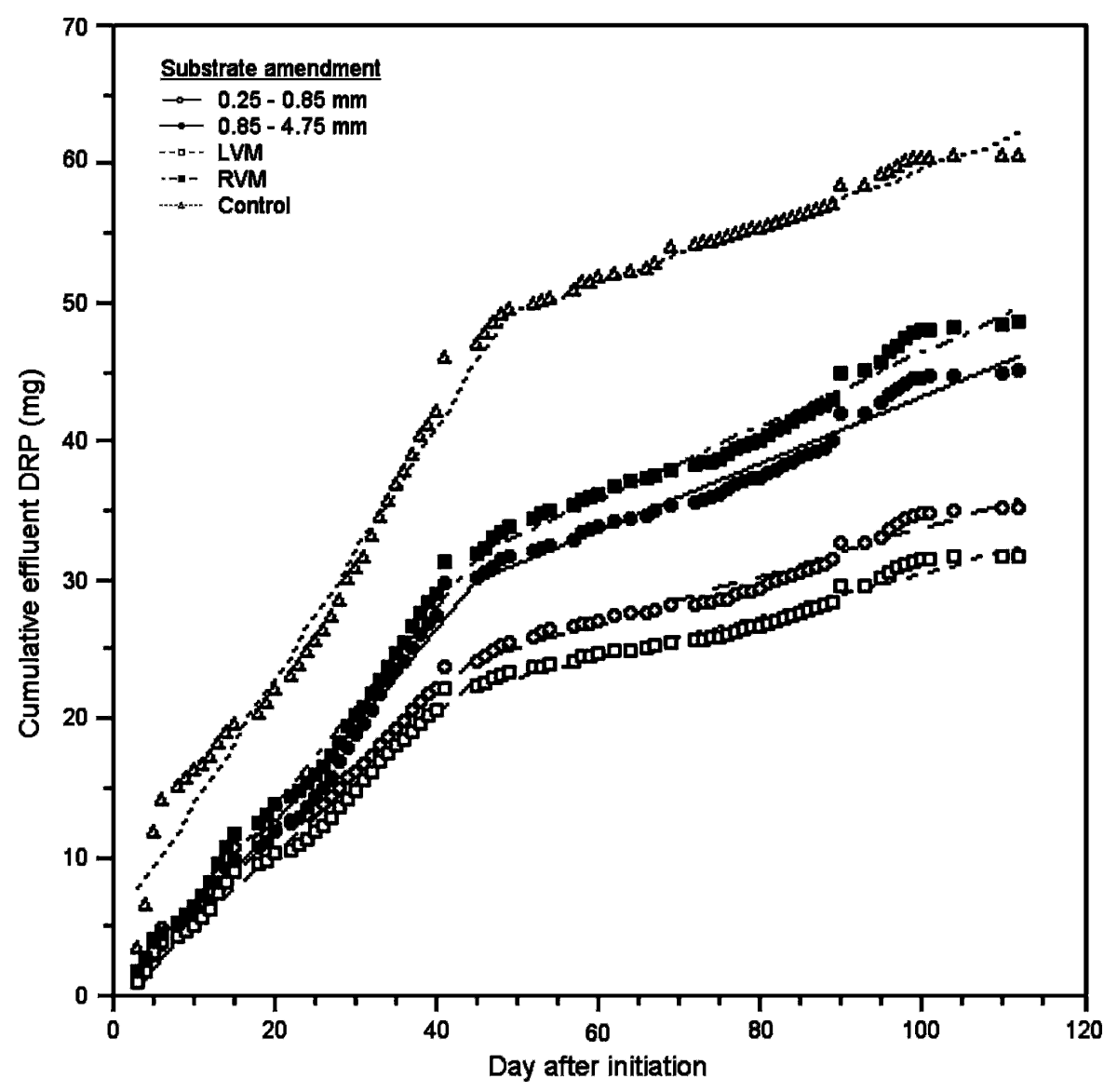

Fig. 3. Cumulative effluent dissolved reactive phosphorus (DRP) for Skogholm cotoneaster grown $112 \mathrm{~d}$ in pine bark substrates amended (by volume) with $11 \%$ sand (control) or $8 \%$ Georgiana bentonitepalygorksite clay mineral aggregate with two particle sizes and two temperature pretreatments (LVM or RVM). All treatments had $1.3 \mathrm{~g}$ of elemental phosphorus surface incorporated at the initiation of the experiment. Segmented linear models for 0.25 to $0.85 \mathrm{~mm}$ : if $\mathrm{x} \leq 44$, then $\mathrm{y}=1.3+0.52 \mathrm{x}, R^{2}=0.99$; if $\mathrm{x} \geq 44$, then $\mathrm{y}=16.5+0.17 \mathrm{x}, R^{2}=0.96 ; 0.85$ to $4.75 \mathrm{~mm}$ : if $\mathrm{x} \leq 45$, then $\mathrm{y}=-1.6+0.70 \mathrm{x}, R^{2}=0.99$; if $\mathrm{x} \geq 45$, then $\mathrm{y}=19.0+0.24 \mathrm{x}, R^{2}=0.97$; LVM: if $\mathrm{x} \leq 43$, then $\mathrm{y}=0.2+0.50 \mathrm{x}, R^{2}=0.99$, if $\mathrm{x} \geq 43$, then $\mathrm{y}=15.4+0.15 \mathrm{x}, R^{2}=0.96$; RVM: if $\mathrm{x} \leq 46$, then $\mathrm{y}=-0.5+0.71 \mathrm{x}, R^{2}=0.99$; if $\mathrm{x} \geq 46$, then $\mathrm{y}=$ $20.1+0.26 \mathrm{x}, R^{2}=0.97$; control: if $\mathrm{x} \leq 49$, then $\mathrm{y}=5.1+0.91 \mathrm{x}, R^{2}=0.98 ;$ if $\mathrm{x} \geq 49$, then $\mathrm{y}=39.5+$ $0.21 \mathrm{x}, R^{2}=0.97 . \mathrm{LVM}=$ low volatile material; $\mathrm{RVM}=$ regular volatile material.

Table 2. Dissolved reactive phosphorus extracted from a pine bark substrate amended (by volume) with $11 \%$ sand (control) or $8 \%$ Georgiana bentonite-palygorksite clay mineral aggregate with two temperature pretreatments and two particle sizes in which Skogholm cotoneaster was grown for $112 \mathrm{~d}{ }^{2}$

\begin{tabular}{|c|c|c|}
\hline \multirow[b]{3}{*}{ Treatments } & \multicolumn{2}{|c|}{ Phosphorus extractant } \\
\hline & $\overline{0.1 \mathrm{M} \mathrm{KCl}}$ & Nanopure $\mathrm{H}_{2} \mathrm{O}$ \\
\hline & \multicolumn{2}{|c|}{ - mg DRP dm ${ }^{-3}$} \\
\hline Control $^{\mathrm{y}}$ & $3.3^{* x}$ & $10.8^{*}$ \\
\hline \multicolumn{3}{|c|}{ Temp. pretreatment $\mathrm{w}^{\mathrm{w}}$} \\
\hline LVM & $4.1^{\mathrm{v}}$ & 15.9 \\
\hline RVM & 8.4 & 24.3 \\
\hline \multicolumn{3}{|c|}{ Particle size $(\mathrm{mm})$} \\
\hline 0.25 to 0.85 & $4.7^{\mathrm{u}}$ & 17.5 \\
\hline 0.85 to 4.75 & 7.8 & 22.8 \\
\hline Temp $(\mathrm{T})$ & $0.002^{\mathrm{t}}$ & 0.03 \\
\hline Size $(\mathrm{S})$ & 0.008 & 0.13 \\
\hline $\mathrm{T} \times \mathrm{S}$ & 0.23 & 0.90 \\
\hline
\end{tabular}

${ }^{\mathrm{z}}$ Each container had $1.3 \mathrm{~g}$ of elemental $\mathrm{P}$ surface incorporated at the initiation of the experiment.

${ }^{\mathrm{y}}$ Industry representative substrate $(\mathrm{n}=3) ; 8$ pinebark: 1 sand.

${ }^{x}$ Asterisks denote significant difference from the mean of the pooled mineral aggregate-amended substrates from the control determined by orthogonal contrast statements $(P \leq 0.05)$.

${ }^{\mathrm{w}}$ Mineral aggregate temperature pretreatment $(\mathrm{n}=3)$ : low volatile material $(\mathrm{LVM})=$ calcined, regular volatile material $(\mathrm{RVM})=$ pasteurized.

${ }^{v}$ Pooled over mineral aggregate particle size $(n=6)$.

uPooled over mineral aggregate temperature pretreatment $(n=6)$.

${ }^{t} P$ values. could have been desorbing $\mathrm{P}$ resulting in greater quantities of $\mathrm{P}$ loss. This is supported by the increase in extractable $P$ that occurs in a mineral versus sand amended substrate (Table 2). However, we speculate 0.25 to $0.85 \mathrm{~mm}$ or LVM aggregates possibly continued sorbing $\mathrm{P}$ because their rate of $\mathrm{P}$ release remained lower than other treatments, DRP at $0.17 \mathrm{mg} \cdot \mathrm{d}^{-1}$ or $0.15 \mathrm{mg} \cdot \mathrm{d}^{-1}$, respectively (Fig. 3). Extractable P averaged across mineral aggregate-amended substrates increased $89 \%$ and $87 \%$ when extracted with water or $0.1 \mathrm{M} \mathrm{KCl}$, respectively, compared with the control substrate (Table 2). Thus, although the absolute quantities of extractable $\mathrm{P}$ varied with extractant, the quantities were consistent between mineral aggregate and sand-amended. It is uncertain why water resulted in greater extractable $\mathrm{P}$ than $0.1 \mathrm{M}$ $\mathrm{KCl}$. These differences in extractable $\mathrm{P}$ may have been a result a different ionic strength and $\mathrm{pH}$-buffering capacity of the extractant.

Mineral aggregate-amended substrates affected the chemical properties of the substrate by increasing $\mathrm{K}$ and $\mathrm{S}$ substrate content an average of $250 \%$ and $131 \%$, respectively, when compared with the control (Table 3). Calcium and $\mathrm{Mg}$ substrate content also increased similarly when amended with a mineral aggregate amendment (data not presented). However, the quantities of these nutrients that were available to the plant were not known. Low $\mathrm{S}$ has been reported to limit plant growth in soilless substrates (Browder et al., 2005); however, little research has been conducted on the base cations. In addition, CEC of aggregate-amended substrates were increased an average of $75 \%$ when compared with the control. The average mineral aggregate-amended substrate raised $\mathrm{pH} 0.4$ units above the control (Table 3). Furthermore, substrates amended with LVM mineral aggregates increased $\mathrm{pH} \quad 0.5$ above the RVM aggregates.

The increased nutrient-buffering capacity of substrates amended with mineral aggregates resulted in an average 32\% increase in the top and root $\mathrm{P}$ content of Skogholm cotoneaster compared with the control (Table 4). The increased water-buffering capacity in association with $\mathrm{P}$ retention of the mineral aggregate-amended substrate resulted in a $20 \%$ to $48 \%$ decrease in effluent DRP load and a $125 \%$ to $154 \%$ increase in substrate water or $\mathrm{KCl}$-extractable $\mathrm{P}$, respectively, compared with the control. These factors combined to increase $\mathrm{P}$ uptake efficiency (PUE) from $27 \%$ in sand-amended substrates to an average $36 \%$ in aggregate-amended substrate. This was also reflected in the average daily effluent $\mathrm{P}$ concentration with the aggregate-amended substrate averaging $1.3 \mathrm{mg} \cdot \mathrm{L}^{-1}$ (Fig. 4). Warren et al. (1995) reported resin-coated $\mathrm{P}$ in a CRF resulted in the highest $\mathrm{P}$ use efficiency (43\%) with a low, constant rate of $\mathrm{P}$ loss at $\approx 1 \mathrm{mg} \cdot \mathrm{d}^{-1}$ when growing Sunglow azalea in $3.8-\mathrm{L}$ containers in a pine bark substrate.

Regardless of particle size, the LVM aggregate reduced the $\mathrm{P}$ lost in the effluent compared with the control, whereas RVM did 
Table 3. Nutrient content, cation exchange capacity, and pH of substrates amended (by volume) with $11 \%$ sand (control) or $8 \%$ Georgiana bentonite-palygorksite clay mineral aggregate with two temperature pretreatments and two particle sizes. ${ }^{\mathrm{z}}$

\begin{tabular}{|c|c|c|c|c|}
\hline \multirow[b]{3}{*}{ Treatments } & \multicolumn{2}{|c|}{$\begin{array}{c}\text { Substrate nutrient } \\
\text { content }^{y}\end{array}$} & \multirow{3}{*}{$\begin{array}{c}\text { Cation } \\
\text { exchange } \\
\text { capacity } \\
\mathrm{mEq} .100 \mathrm{~cm}^{-3}\end{array}$} & \multirow[b]{3}{*}{$\mathrm{pH}^{\mathrm{x}}$} \\
\hline & $\mathrm{K}$ & $\mathrm{S}$ & & \\
\hline & \multicolumn{2}{|c|}{---------- $\mathrm{mg} \mathrm{dm}{ }^{-3}$} & & \\
\hline Control $^{\mathrm{w}}$ & $26^{* v}$ & $29 *$ & $8 *$ & $5.1^{*}$ \\
\hline \multicolumn{5}{|c|}{ Temp. pretreatment ${ }^{\mathrm{u}}$} \\
\hline LVM & $102^{\mathrm{t}}$ & 64 & 14 & 5.7 \\
\hline RVM & 79 & 69 & 13 & 5.2 \\
\hline \multicolumn{5}{|c|}{ Particle size, $\mathrm{mm}$} \\
\hline 0.25 to 0.85 & $106^{\mathrm{s}}$ & 78 & 14 & 5.6 \\
\hline 0.85 to 4.75 & 75 & 55 & 13 & 5.3 \\
\hline Temp (T) & $0.07^{\mathrm{r}}$ & 0.55 & 0.32 & 0.03 \\
\hline Size $(\mathrm{S})$ & 0.03 & 0.03 & 0.02 & 0.17 \\
\hline $\mathrm{T} \times \mathrm{S}$ & 0.39 & 0.16 & 0.45 & 0.59 \\
\hline
\end{tabular}

${ }^{\mathrm{z}}$ At the initiation of the experiment, all substrates were amended with $0.6 \mathrm{~kg} \cdot \mathrm{m}^{-3}$ ground dolomitic limestone $\left[\mathrm{CaMg}\left(\mathrm{CO}_{3}\right)_{2}\right]$ and each container had $60 \mathrm{~g} 17 \mathrm{~N}-5 \mathrm{P}_{2} \mathrm{O}_{5}-12 \mathrm{~K}_{2} \mathrm{O} 5$ to 6 months controlledrelease fertilizer containing $2.3 \mathrm{~g} \mathrm{~S}$ surface incorporated.

${ }^{\mathrm{y}}$ Nutrient content determined using Mechlich III extractant after $112 \mathrm{~d}$.

${ }^{\mathrm{x}} \mathrm{pH}$ determined using pourthrough method after $65 \mathrm{~d}$.

wIndustry representative substrate $(\mathrm{n}=3) ; 8$ pinebark:1 sand (by volume).

${ }^{\mathrm{v}}$ Asterisks denote significant difference from the mean value of the pooled mineral aggregates determined by orthogonal contrast statements, $P \leq 0.05$.

${ }^{u}$ Mineral aggregate temperature pretreatment $(\mathrm{n}=3)$ : low volatile material $(\mathrm{LVM})=$ calcined, regular volatile material $(\mathrm{RVM})=$ pasteurized.

tPooled over mineral aggregate particle size $(n=6)$.

sPooled over mineral aggregate temperature pretreatment $(n=6)$.

${ }^{\mathrm{r}} P$ values.

Table 4. Distribution of $\mathrm{P}$ for Skogholm cotoneaster grown $112 \mathrm{~d}$ in pine bark substrates amended (by volume) with $11 \%$ sand (control) or $8 \%$ Georgiana bentonite-palygorksite clay mineral aggregate with two particle sizes and two temperature pretreatments. ${ }^{\mathrm{z}}$

\begin{tabular}{|c|c|c|c|c|c|}
\hline \multirow[b]{3}{*}{ Phosphorus(mg) } & \multirow[b]{3}{*}{ Control $^{\mathrm{y}}$} & \multicolumn{4}{|c|}{$\begin{array}{l}\text { Mineral aggregate } \\
\text { amended substrate }\end{array}$} \\
\hline & & \multicolumn{2}{|c|}{0.25 to $0.85 \mathrm{~mm}^{\mathrm{x}}$} & \multicolumn{2}{|c|}{0.85 to $4.75 \mathrm{~mm}$} \\
\hline & & $\mathrm{LVM}^{\mathrm{w}}$ & RVM & LVM & RVM \\
\hline Leachate DRP & $61 \mathrm{a}^{\mathrm{v}}$ & $24 \mathrm{c}$ & $47 \mathrm{ab}$ & $40 \mathrm{bc}$ & $50 \mathrm{ab}$ \\
\hline \multicolumn{6}{|l|}{ Cotoneaster total $\mathrm{P}$} \\
\hline $\operatorname{Root}^{\mathrm{u}}$ & $25 \mathrm{c}$ & $34 \mathrm{~b}$ & $33 \mathrm{~b}$ & $33 \mathrm{~b}$ & $42 \mathrm{a}$ \\
\hline Top $^{t}$ & $186 \mathrm{~b}$ & $238 \mathrm{ab}$ & $246 \mathrm{a}$ & $224 \mathrm{a}$ & $264 \mathrm{a}$ \\
\hline $\begin{array}{l}\text { Substrate extracted DRP } \\
\text { (Mehlich III) }\end{array}$ & $6^{\mathrm{s}}$ & 12 & 9 & 15 & 11 \\
\hline Ferilizer prill DRP & $526^{\mathrm{s}}$ & 471 & 600 & 593 & 503 \\
\hline P uptake efficiency (\%) & 27 & 32 & 39 & 35 & 38 \\
\hline \multicolumn{6}{|l|}{ Recovered } \\
\hline Phosphorus $^{\mathrm{q}}$ & $763^{\mathrm{s}}$ & 765 & 906 & 876 & 834 \\
\hline Percent $^{\mathrm{p}}$ & $62^{\mathrm{s}}$ & 60 & 72 & 70 & 67 \\
\hline
\end{tabular}

${ }^{\mathrm{z}}$ All treatments had $1300 \mathrm{mg}$ of elemental P surface incorporated at the initiation of the experiment.

y Industry representative substrate $(\mathrm{n}=3) ; 8$ pinebark: 1 sand (by volume).

${ }^{\mathrm{x}}$ Mineral aggregate particle size $(\mathrm{n}=3)$ with equivalent U.S. standard: $24 / 48$ mesh $(0.25$ to $0.85 \mathrm{~mm}), 4 / 20$ mesh ( 0.85 to $4.75 \mathrm{~mm})$.

${ }^{w}$ Mineral aggregate temperature pretreatment $(n=3)$ : low volatile material $(L V M)=$ calcined, regular volatile material $(\mathrm{RVM})=$ pasteurized.

'Means separated within row by Fisher's protected least significant difference $(P=0.05)$.

uPooled root dry weight for all treatments $=30 \mathrm{~g}$.

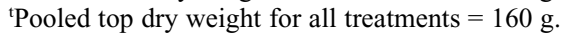

sot significant.

${ }^{\mathrm{r}} \mathrm{P}$ uptake efficiency $=[$ plant $\mathrm{P} \div(\mathrm{P}$ applied $-\mathrm{P}$ remaining in fertilizer prill - substrate $\mathrm{P})] \times 100$.

${ }^{\mathrm{q}}$ Recovered $\mathrm{P}=$ leachate + plant + substrate + fertilizer prill

pPercent recovered $\mathrm{P}=($ recovered $\mathrm{P} \div$ applied $\mathrm{P}) \times 100$.

not (Table 4). The CRF prills retained an average $41 \%($ mean $=539 \mathrm{mg} \pm 25 \mathrm{SE})$ of the applied $1.3 \mathrm{~g}$ of elemental $\mathrm{P}$ accounting for $65 \%$ of the recovered $\mathrm{P}$ (mean $=829 \mathrm{mg} \pm$ $29 \mathrm{SE}$ ) (Table 4). Plant PUE was 5\% to $12 \%$ greater in a mineral-amended substrate (mean $=36 \% ; P=0.07, \mathrm{~F}=4.0)$ compared with the control (27\%) (Table 4). ized Skogholm cotoneaster with $800 \mathrm{~mL} \cdot \mathrm{d}^{-1}$; however, top and root dry weight were maximized at this irrigation volume, although observed substrate solution $\mathrm{P}$ concentrations decreased as low as $1.8 \mathrm{mg} \mathrm{P} \mathrm{L}^{-1}$ and $0.1 \mathrm{mg} \mathrm{P} \mathrm{L}^{-1}$ at $60 \mathrm{DAI}$ and $119 \mathrm{DAI}$, respectively (Groves et al., 1998a). Lea-Cox and Ristvey (2003) suggested an $80 \%$ reduction in current rate of $\mathrm{P}$ application, thus making the optimal $\mathrm{P}$ substrate solution concentration $2 \mathrm{mg} \cdot \mathrm{L}^{-1}$ or less, increasing PUE to $75 \%$ when adequate $\mathrm{N}$ is applied.

Effluent $\mathrm{N}$ content, total plant $\mathrm{N}$ content, and $\mathrm{N}$ uptake efficiency were unaffected by substrate amendment (Table 5). However, mean daily effluent $\mathrm{N}$ concentration over the 112 -d study was reduced $22 \%$ from 8.4 $\mathrm{mg} \cdot \mathrm{L}^{-1}$ to $6.5 \mathrm{mg} \cdot \mathrm{L}^{-1}$ when the pine bark substrate was amended with an LVM aggregate versus RVM aggregate (Fig. 4). CRF prills contained $26 \%$ of the total applied $\mathrm{N}$ after 112 DAI, $42 \%$ being $\mathrm{NH}_{4}-\mathrm{N}$ and $10 \%$ $\mathrm{NO}_{3}-\mathrm{N}$ accounting for $55 \%$ of the recovered $\mathrm{N}$ after 112 DAI (Table 5). Three percent $($ mean $=149 \mathrm{mg} \pm 13 \mathrm{SE})$ of $\mathrm{N}$ was leached and $38 \%($ mean $=1814 \mathrm{mg} \pm 30 \mathrm{sE})$ of $\mathrm{N}$ was taken up by the plant. No substrate $\mathrm{NO}_{3}-\mathrm{N}$ or $\mathrm{NH}_{4}-\mathrm{N}$ could be detected with either water or $0.1 \mathrm{~mol} \cdot \mathrm{L}^{-1} \mathrm{KCl}$ extractant. Nitrogen use efficiency in this study is lower than previously reported, probably because it was calculated based on elemental $\mathrm{N}$ and not $\mathrm{N}$ species (Tyler et al., 1996). The authors hypothesize that the unaccountable portion of $\mathrm{N}$ was primarily lost through denitrification and a minor portion of $\mathrm{N}$ was lost to immobilization or volatilization.

Plant response. Top $(160 \mathrm{~g} \pm 4 \mathrm{SE})$ and root (mean $=30 \mathrm{~g} \pm 1 \mathrm{SE}$ ) dry weight of Skogholm cotoneaster were unaffected by any of the treatments (data not presented). However, water required to produce $1 \mathrm{~g}$ dry weight $\left(\mathrm{WUE}_{\mathrm{P}}\right.$ ) was affected by treatments (data not presented). Skogholm cotoneaster grown in aggregate-amended substrates required an average of $607 \pm 4 \mathrm{~mL}$ to produce $1 \mathrm{~g}$ of plant dry weight, whereas cotoneaster grown in the control substrate required $731 \mathrm{~mL}$ to produce $1 \mathrm{~g}$ of plant dry weight, resulting in a $17 \%$ increase in $W E_{P}$. We speculate this is a reflection of increased $\mathrm{CC}$ and $\mathrm{AW}$ in aggregate-amended substrates (Table 1).

Phosphorus (Table 4) and K (data not presented) content of Skogholm cotoneaster were $32 \%$ and $49 \%$ greater, respectively, when grown in a mineral-amended substrate versus sand-amended substrate. Top or root $\mathrm{N}, \mathrm{Ca}, \mathrm{Mg}, \mathrm{S}, \mathrm{Fe}, \mathrm{Mn}, \mathrm{B}, \mathrm{Mo}$, and $\mathrm{Cl}$ content were unaffected by mineral aggregate amendments nor were there any differences with the control (data not presented).

CER was 20\% greater in Skogholm cotoneaster grown in mineral-amended substrates $\left(\right.$ mean $\left.=8.2 \mu \mathrm{mol} \cdot \mathrm{m}^{-2} \cdot \mathrm{s}^{-2} \pm 0.3 \mathrm{sE}\right)$ versus Skogholm cotoneaster grown in the control substrate $\left(\right.$ mean $\left.=6.9 \mu \mathrm{mol} \cdot \mathrm{m}^{-2} \cdot \mathrm{s}^{-2} \pm 0.9 \mathrm{SE}\right)$ without induced drought stress (data not presented). CER and $g_{s}$ was $25 \%$ and $33 \%$ greater, respectively, after $42 \mathrm{~h}$ without irrigation when cotoneaster was grown in a mineral-amended substrate compared with 


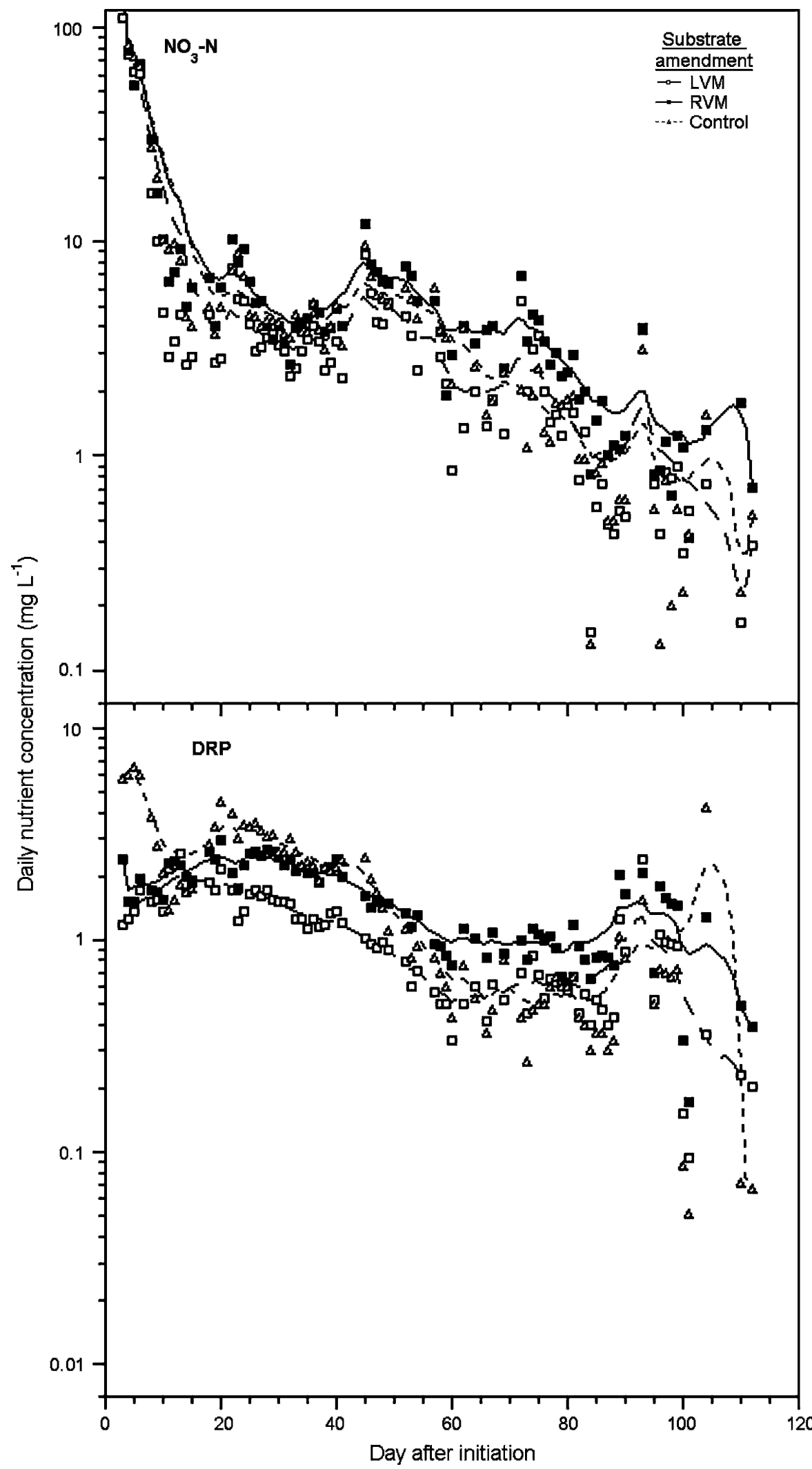

Fig. 4. Daily effluent nutrient concentration of $\mathrm{NO}_{3}-\mathrm{N}$ and dissolved reactive phosphorus (DRP) for Skogholm cotoneaster grown $112 \mathrm{~d}$ in pine bark substrates amended (by volume) with $11 \%$ sand (control) or $8 \%$ Georgiana bentonite-palygorksite clay mineral aggregate with two temperature pretreatments (LVM or RVM). All treatments had $5.1 \mathrm{~g} \mathrm{NO}_{3}-\mathrm{N}$ and $1.3 \mathrm{~g}$ of elemental phosphorus surface incorporated at the initiation of the experiment. Municipal water applied contained an average $\mathrm{NO}_{3}-\mathrm{N}$ and $\mathrm{P}$ concentration of less than $0.1 \mathrm{mg} \mathrm{L}^{-1}$ and less than $0.05 \mathrm{mg} \mathrm{L}^{-1}$, respectively. $\mathrm{LVM}=1 \mathrm{ow}$ volatile material; $\mathrm{RVM}=$ regular volatile material.
Table 5. Distribution of $\mathrm{N}$ for Skogholm cotoneaster grown for $112 \mathrm{~d}$ in pine bark-based substrates amended (by volume) with sand at $11 \%$ or industrial aggregate at $8 \%{ }^{\mathrm{z}}$

\begin{tabular}{lc}
\hline Elemental N (mg) & Pooled Mean \\
\hline Effluent & $72^{\mathrm{y}} \pm 4$ \\
$\quad$ Nitrate-N & $77 \pm 11$ \\
$\quad$ Ammonium-N & $1944 \pm 30$ \\
Cotoneaster & 0 \\
Substrate & \\
Fertilizer prill & $536 \pm 28$ \\
$\quad$ Nitrate-N & $2088 \pm 92$ \\
$\quad$ Ammonium-N & $26 \pm 1$ \\
N uptake efficiency & $(\%)$ \\
Recovered & \\
$\quad$ Elemental N & \\
$\quad$ Percent $^{\mathrm{v}}$ & $4718 \pm 117$ \\
\hline
\end{tabular}

${ }^{\mathrm{z}}$ All treatments had 10,200 mg of elemental $\mathrm{N}$ topdressed and surface-incorporated at the initiation of the experiment.

${ }^{\mathrm{y}} \mathrm{Mean} \pm \mathrm{SE}$.

${ }^{\mathrm{x}} \mathrm{N}$ efficiency $=[$ plant $\mathrm{N} \div$ (plant $\mathrm{N}$ applied $-\mathrm{N}$ remaining in fertilizer prill) $] \times 100$.

${ }^{\text {w }}$ Recovered $\mathrm{N}=$ leachate + plant + substrate + fertilizer prill.

vercent recovered $\mathrm{N}=($ recovered $\mathrm{N} \div \operatorname{applied} \mathrm{N})$ $\times 100$

cotoneaster grown in the control substrate (Owen et al., 2003). Mineral aggregate temperature pretreatment had greater influence on CER and $g_{s}$ than mineral aggregate particle size. After $42 \mathrm{~h}$ without irrigation, plants grown in substrates amended with LVM mineral aggregates had $27 \%$ higher CER $\left(\right.$ mean $\left.=8.7 \mu \mathrm{mol} \cdot \mathrm{m}^{-2} \cdot \mathrm{s}^{-2} \pm 0.8 \mathrm{SE}\right)$ and $43 \%$ higher $g_{s}\left(\right.$ mean $\left.=0.13 \mathrm{~mol} \cdot \mathrm{m}^{-2} \cdot \mathrm{s}^{-1} \pm 0.02 \mathrm{SE}\right)$ compared with plants grown in substrates amended with RVM aggregates (mean CER $=6.9 \mu \mathrm{mol} \cdot \mathrm{m}^{-2} \cdot \mathrm{s}^{-2} \pm 0.6 \mathrm{SE} ;$ mean $g_{s}=0.09$ $\mathrm{mol} \cdot \mathrm{m}^{-2} \cdot \mathrm{s}^{-1} \pm 0.01 \mathrm{sE}$ ) (Owen et al., 2003). Plant response was further separated by particle size, with plants grown in substrates amended with 0.25 - to $0.85-\mathrm{mm}$ aggregates $\left(\right.$ mean $\left.=0.03 \mathrm{~mol} \cdot \mathrm{m}^{-2} \cdot \mathrm{s}^{-1} \pm 0.006 \mathrm{SE}\right)$ having greater $g_{s}$ compared with plants grown in substrates amended with $0.85-$ to $4.75-\mathrm{mm}$ aggregates $\left(\right.$ mean $=0.02 \mathrm{~mol} \cdot \mathrm{m}^{-2} \cdot \mathrm{s}^{-1} \pm 0.001$ $\mathrm{SE})$ after $67 \mathrm{~h}$ without irrigation. After $71 \mathrm{~h}$ without irrigation, all treatments had similar levels of CER and $g_{s}$ (data not presented).

Pine bark amended with industrial mineral aggregates increased water and nutrient efficiency without affecting root or top growth of Skogholm cotoneaster. This modified substrate offers a way to reduce environmental impact of nursery crop production compared with traditional means of lowering input quantities. If input quantities become growth-limiting, the result is decreased nutrient uptake efficiency attributable to less plant growth and root exploitation, which results in increased mineral nutrient leaching (Tyler et al., 1996). Mineral aggregateamended substrates increased WUE $_{P} 17 \%$ and decreased water applied $26 \mathrm{~L}$ per $14-\mathrm{L}$ container over the growing season when compared with pine bark amended with sand. Substrate CEC was greater than $75 \%$ in mineral- versus sand-amended substrates increasing substrate base cation content. 
Mineral aggregate-amended substrate had a $125 \%$ to $154 \%$ increase in $\mathrm{KCl} /$ waterextractable $\mathrm{P}$, which in turn raised top $\mathrm{P}$ content of Skogholm cotoneaster 32\% compared with the control. Average daily effluent DRP concentration was $0.8 \mathrm{mg} \cdot \mathrm{L}^{-1}$, which is greater than the USEPA MCL goal for waters. Therefore, with current rate of $\mathrm{P}$ fertilization, effluent concentrations that meet USEPA criteria may not be attainable for nurseries recycling water alone. Average daily $\mathrm{NO}_{3}-\mathrm{N}$ concentration remained below USEPA MCLs from 20 to 112 DAI. A pine bark soilless substrate amended with 0.25 to $0.85 \mathrm{~mm}$ LVM industrial mineral aggregate can reduce effluent DRP and $\mathrm{NH}_{4}-\mathrm{N}$ and reduce water application volume when compared with a sand-amended bark-based substrate without sacrificing plant growth.

\section{Literature Cited}

Browder, J.F., A.X. Niemiera, J.R. Harris, and R.D. Wright. 2005. Growth of container grown pin oak and Japanese maple as influenced by sulfur and sulfated micronutrients. HortScience 40:1521-1523.

Calado, D.A., M. Haroon, L.E. Schrader, and V.L. Youngs. 1975. Rapid colorimetric determination of nitrate in plant tissue. Commun. Soil Sci. Plant Anal. 6:71-80.

Carpenter, S.R. 2005. Europhication of aquatic ecosystems: Bistability and soil phosphorus. Proc. Natl. Acad. Sci. USA 102:10002-10005.

Chaney, A.L. and E.P. Marbach. 1962. Modified reagents for determination of urea and ammonia. Clin. Chem. 8:130-132.

Fonteno, W.C. and T.E. Bilderback. 1993. Impact of hydrogel on physical properties of coarsestructured horticultural substrates. J. Amer. Soc. Hort. Sci. 118:217-222.

Foster, W.J., R.D. Wright, M.M. Alley, and T.H. Yeager. 1983. Ammonium adsorption on pine bark growing medium. J. Amer. Soc. Hort. Sci. 108:548-551.

Frink, C.R., P.E. Waggoner, and J.H. Ausubel. 1999. Nitrogen fertilizer: Retrospect and prospect. Proc. Natl. Acad. Sci. USA 96:1175-1180.

Groves, K.M., S.L. Warren, and T.E. Bilderback. 1998a. Irrigation volume, application, and controlled release fertilizers: I. Effect on plant growth and mineral nutrient content in containerized plant production. J. Environ. Hort. 16:176-181.
Groves, K.M., S.L. Warren, and T.E. Bilderback. 1998b. Irrigation volume, application, and controlled release fertilizers: II. Effect on substrate solution nutrient concentration and water efficiency in containerized plant production. J. Environ. Hort. 16:182-188.

Handreck, K. and N. Black. 2002. Growing media for ornamental plants and turf. 3rd ed. UNSW Press, Sydney, Australia.

Hart, M.R., F.Q. Bert, and M. Long Nguyen. 2004 Phosphorus runoff form and agricultural land and direct fertilizer effects: A review. J. Environ. Qual. 33:1954-1972.

Lea-Cox, J.D. and A.G. Ristvey. 2003. Why are nutrient uptake efficiencies so low in ornamental plant production? Proc. SNA Res. Conf., 48th Annu. Rpt. p. 116-122.

Malakoff, D. 1998. Death by suffocation in the gulf of Mexico. Science 281:190-192.

Marini, R.P. 1999. Are nonsignificant differences really not significant? HortScience 34: 761-762.

Mehlich, A. 1984a. Mehlich-3 soil test extractant: A modification of Mehlich-2 extractant. Commun. Soil Sci. Plant Anal. 15:1409-1416.

Mehlich, A. 1984b. Photometric determination of humic matter in soils, a proposed method. Commun. Soil Sci. Plant Anal. 15:1417-1422.

Mehlich, A., S.S. Bowling, and A.L. Hatfield. 1976. Buffer $\mathrm{pH}$ acidity in relation to nature of soil acidity and expression of lime requirement. Commun. Soil Sci. Plant Anal. 7: 253-263.

Milks, R.R., W.C. Fonteno, and R.A. Larson. 1989. Hydrology of horticultural substrates: I. Predicting physical properties of media in containers. J. Amer. Soc. Hort. Sci. 114:53-56.

Moll, W.F. and G.R. Goss. 1997. Mineral carriers for pesticides-Their characteristics and uses. Standard Tech. Publ. 943. Amer. Soc. Testing and Materials, West Conshohocken, PA.

Murphy, J. and J.P. Riley. 1962. A modified single solution method for the determination of phosphate in natural waters. Anal. Chim. Acta 27:31-36.

Murray, H.H. 2000. Traditional and new applications for kaolin, smectite, and palygorskite: A general overview. Appl. Clay Sci. 17: 207-221.

Niemiera, A.X. and R.D. Wright. 1986. The influence of nitrification on the medium solution and growth of holly, azalea, and juniper in a pine bark medium. J. Amer. Soc. Hort. Sci. 111:708-712.

Nosengo, N. 2003. Fertilized to death. Nature 425:894-895.
Owen J.S., Jr., S.L. Warren, and T.E. Bilderback. 2003. Clay amended pine bark influences irrigation volume and water buffering capacity. Proc. SNA Res. Conf., 48th Annu. Rpt. p. 20-23.

Reed, D.Wm. 1996. Water, media, and nutrition for greenhouse crops. Ball Publishing, Batavia, IL.

Riviere, L.M., J.C. Foucard, and F. Lemaire. 1990. Irrigation of container crops according to the substrate. Scientia Hort. 43:339-349.

SAS Institute. 2001. The SAS system for Windows. Release 8.2. SAS Inst., Cary, NC.

Sonneveld, C., J. van den Ende, and P.A. van Dijk. 1974. Analysis of a growing media by means of a $1: 1 \frac{1}{2}$ volume extract. Commun. Soil Sci. Plant Anal. 5:183-202.

Spomer, L.A. 1998. Water retention of light expanded clay amendment. Commun. Soil Sci. Plant Anal. 29:1265-1276.

Tucker, M.R. 1984. Volumetric measures for routine soil testing. Commun. Soil Sci. Plant Anal. 15:833-840.

Tyler, H.H., S.L. Warren, and T.E. Bilderback. 1996. Reduced leaching fractions improve irrigation use efficiency and nutrient efficacy. J. Environ. Hort. 14:199-204.

USDA. 2004. Nursery Crops 2003 Summary. Office of Natl. Agr. Stat. Serv., U.S. Dept. Agr., Washington, DC. 15 May 2005. <www. usda.mannlib.cornell.edu/reports nassr/other/ nursery/>.

USEPA. 1987. Agricultural chemicals in groundwater: Proposed strategy. Office of Pesticides and Toxic Substances, U.S. Environ. Protection Agency, Washington, DC.

Warren, S.L. and T.E. Bilderback. 1992. Arcillite: Effect on chemical and physical properties of pine bark substrate and plant growth. J. Environ. Hort. 10:63-69.

Warren, S.L. and T.E. Bilderback. 2005. More plant per gallon: Getting more out of your water. HortTechnology 15:14-18.

Warren, S.L., T.E. Bilderback, and H.H. Tyler. 1995. Efficacy of three nitrogen and phosphorus sources in container grown azalea production. J. Environ. Hort. 13:147-151.

Williams, K.A. and P.V. Nelson. 2000. Phosphate and potassium retention and release during chrysanthemum production from precharged materials: II. Calcined clay and brick chips. J. Amer. Soc. Hort. Sci. 125:757-764.

Yeager, T.H., T. Bilderback, D. Fare, C. Gilliam, A. Niemiera, and K. Tilt. 1997. Best management practices-Guide for producing container-grown plants. Southern Nursery Assoc., Atlanta, GA. 